\title{
THE INFLUENCE OF EDUCATIONAL BACKGROUND AND WORK EXPERIENCE ON EMPLOYEES PERFORMANCE AT PT. THREE CAST INDONESIA
}

\author{
$1^{\text {st }}$ Tika Fadilah \\ Department of Applied Business Administration \\ Administration Batam State Polytechnic \\ Batam City, Riau Island Indonesia \\ tikafadilah2501@gmail.com
}

\author{
$2^{\text {nd }}$ Rahmat Hidayat, S.AB., M.AB \\ Department of Applied Business Administration \\ Administration Batam State Polytechnic \\ Batam City, Riau Island Indonesia \\ rahmat@polibatam.ac.id
}

\begin{abstract}
This research was conducted aimed at knowing how the influence of educational background and work experience on employee performance at PT. Three Cast Indonesia. The results of multiple linear regression can be concluded that (1) the educational background variable has a positive and significant effect on employee performance at PT. Three Cast Indonesia with the acquisition of tcount $6.379>$ ttable 1.661 with a significance value of $0.000<0.05$. (2) variable work experience has a positive and significant effect on the employees performance at PT. Three Cast Indonesia with the acquisition of tcount $8.526>$ ttable 1.661 with a significance value of $0.000<0.05$ (3) simultaneously indicating the variables of educational background and work experience significantly effect on the employees performance at PT. Three Cast Indonesia with a calculated value of $72.925>$ Ftable 3.09 and the significance level obtained is $\mathbf{0 . 0 0 0}$.
\end{abstract}

Keyword - Educational Background, Employee Performance, Performance, Work Experience.

\section{INTRODUCTION}

\section{A. Background}

Employee achievement or work achievement is produced by a person or work contributor within the company organization in carrying out their duties in accordance with their respective authorities and responsibilities in order to achieve the objectives of the illegally approved company organization that applies, and where the work results must be accessed by concrete and can be approved [1]

Education is the foundation and reference for developing and creating broad-minded and high-quality human resource capabilities.

Work experience is an assessment about how long time or work period a person to be able to understand work task and have carried out their work properly [2].

One company that is suspected of having an employee's performance that is not optimal is PT. THREE CAST INDONESIA, which is a manufacturing company engaged in aluminum casting is quite large. The phenomenon that occur in employees to PT. Three Cast Indonesia often shows less optimal performance, both in terms of discipline and in terms of employee work results.

Based on the background explanation outlined above, the authors was moved to conduct a study with the title of "THE INFLUENCE OF EDUCATIONAL BACKGROUND AND WORK EXPERIENCE OF EMPLOYEES PERFORMANCE AT PT. THREE CAST INDONESIA".

\section{B. Formulation of the Problem}

Based on the background above, the authors formulate the following problems:

1. How does the educational background affect the performance of the employees to PT. Three Cast Indonesia?

2. How does the work experience affect the performance to the employees of PT. Three Cast Indonesia?

3. How does the work experience affect the employees performance on PT. Three Cast Indonesia?

C. Objective of the Study

Based by the formulation above, the purpose to be achieved in this study is as follows:

1. To know the influence of the educational background employees on PT. Three Cast Indonesia employee performance

2. To know the influence of the work experience on PT. Three Cast Indonesia employee performance?

3. To know the influence of the educational background and work experience on PT. Three Cast Indonesia employee performance?

\section{Significance of the Study}

As for the benefits obtained from the research conducted by researchers are as follows:

\section{1) Practical benefits}

For the company, the results of this study are expected to be one of the inputs or contributions of thought for PT. Three Cast Indonesia to fix and determine the next step in dealing with 
problems regarding the performance of employees at PT. Three Cast Indonesia. For the academic, the author hopes that this research can add insight and knowledge related to human resource management, especially regarding employee performance. Then for the next researcher, this research can be used as similar research material and as a further research development.

\section{2) Theoretical benefits}

Can increase knowledge in the scientific field and scientific development of writers and readers about human resource management, especially the performance of employees who are influenced by educational background and work experience.

\section{REVIEW OF LITERATURE}

\section{A. Theoretical Study}

1) Education

Education is an effort to educate the nation as stated in [3], namely: Education is a conscious and planned effort to create a learning atmosphere and learning process so that students actively develop their potential to have religious spiritual abilities, self-control, personality, intelligence, noble character, and skills needed by themselves, society, nation and country.

According to ${ }^{[4]}$ Education is the whole process of techniques and methods of learning to teach in order to move the knowledge to each others according to predefined standards.

Educational background can be seen in two terms :

1. Educational level

2. Course spesifications

\section{2) Work Experience}

Experience can be interpreted as something that has been experienced (felt, perceived, responsibility ,etc). [5] stated that the experience raises someone's potential

Factors that influencing work experience :

1. Working Period

2. The level of knowledge and skill owned

3. Control of work and equipment

\section{3) Performance}

The definition of performance according to

$[6]$ is the work result in quality and quantity achieved by an employee in carrying out his/her duties in accordance with responsibilities that given to him/her. Dimension and Performance Indicators :

1. Quantity of work result

2. Quality of work result

3. Punctuality

According to ${ }^{[7]}$ performance is influenced by three factors, namely :

1. Individual factors (ability and expertise, Background, Demographics)
2. Psychological factors (Perception, Attitude, Personality, Learning, Motivation)

3. Organization factors (Resource, Leadership, Appreciation, Structure, Job design)

\section{B. Conceptual Framework}

In this study, there are thought frameworks described in the following figure:

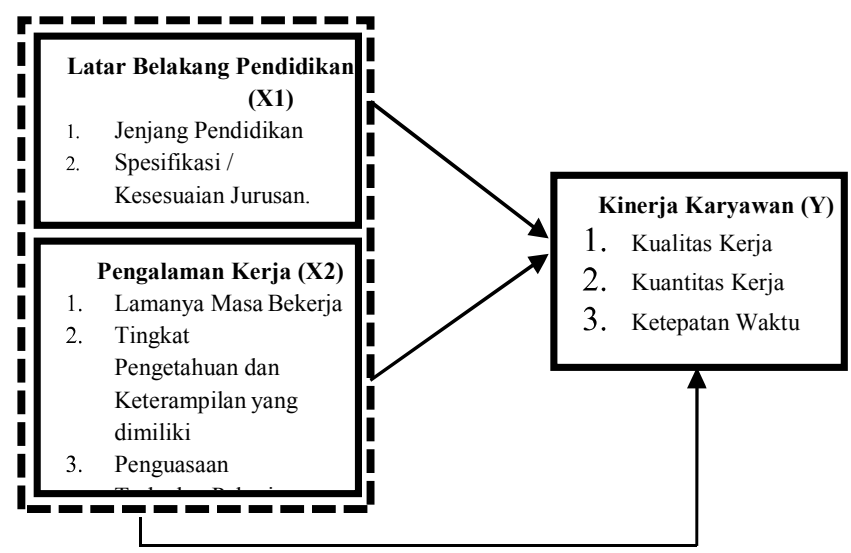

Fig. 1. Conceptual Framework

\section{Hypothesis}

The hypothesis in this study are as follows:

H1: There is a positive and significant influence from the educational background on the employees performance of PT. Three Cast Indonesia.

H2: There is a positive and significant influence from the work experience on the employees performance of PT. Three Cast Indonesia.

H3: There is a simultaneous influence of educational background and work experience on the employees performance of PT. Three Cast Indonesia.

\section{METHOD OF RESEARCH}

\section{A. Research Design}

This type of research uses quantitative methods. Quantitative method research in the form of numbers and analysis using statistics is seemed with the help of questionnaires.

\section{B. Objects and Scope of Research}

The object of this research is all employees of PT. Three Cast Indonesia. The scope of this research is testing to determine the effect of educational background and work experience on the performance of employees at PT. Three Cast Indonesia.

\section{Population and Sample}

The population of this study was 100 employees at PT. Three Cast Indonesia. This sampling uses a non-probability sampling technique that is by sampling saturation. In 
determining the sample of researchers, that is by taking all employee of the population as respondents.

\section{Data Collection Techniques}

The techniques for collecting data in this study are Questionnaires;

According to ${ }^{[8]}$ a questionnaire is a technique of data collection conducted by giving a set of questions that are written statements to the respondent to be asked for answers to the questions listed on the questionnaire.

\section{E. Validity and Reliability}

The questionnaires is said to be valid if the statement can approve something that will measured by a questionnaire. If the result of rtable $<$ rcount, then the instrument is valid. Validity test can also done by comparing the significance value with alpha (0.05) where if the significance value smaller than 0.05 , then the indicator / item statement on questionnaire is valid.

\begin{tabular}{|c|c|c|c|c|c|}
\hline Variable & $\begin{array}{l}\text { State } \\
\text { ment } \\
\text { Item }\end{array}$ & $\begin{array}{l}R \\
\text { tabel }\end{array}$ & $\begin{array}{c}\text { rhitun } \\
\text { g } \\
\text { (Perso } \\
n \\
\text { Correl } \\
\text { ations } \\
\text { ) }\end{array}$ & Status & $\begin{array}{c}\text { Alpha } \\
\text { Cronch } \\
\text { b ach } \\
\text { Status }\end{array}$ \\
\hline \multirow{6}{*}{$\begin{array}{c}\text { Education } \\
\text { Backgrou } \\
\mathrm{nd} \\
\text { (X1) }\end{array}$} & 1 & \multirow{6}{*}{0,1966} & 0,439 & Valid & \multirow{6}{*}{$\begin{array}{c}0,643 \\
\text { Reliable }\end{array}$} \\
\hline & 2 & & 0,753 & Valid & \\
\hline & 3 & & 0,677 & Valid & \\
\hline & 4 & & 0,713 & Valid & \\
\hline & 5 & & 0,729 & Valid & \\
\hline & 6 & & 0,262 & Valid & \\
\hline \multirow{9}{*}{$\begin{array}{c}\text { Work } \\
\text { Experien } \\
\text { ce } \\
(\mathrm{X} 2)\end{array}$} & 1 & \multirow{9}{*}{0,1966} & 0,488 & Valid & \multirow{9}{*}{$\begin{array}{c}0,821 \\
\text { Reliable }\end{array}$} \\
\hline & 2 & & 0,450 & Valid & \\
\hline & 3 & & 0,649 & Valid & \\
\hline & 4 & & 0,679 & Valid & \\
\hline & 5 & & 0,820 & Valid & \\
\hline & 6 & & 0,820 & Valid & \\
\hline & 7 & & 0,541 & Valid & \\
\hline & 8 & & 0,722 & Valid & \\
\hline & 9 & & 0,593 & Valid & \\
\hline \multirow{10}{*}{$\begin{array}{c}\text { Employe } \\
\text { e } \\
\text { Performa } \\
\text { nce } \\
\text { (Y) }\end{array}$} & 1 & \multirow{10}{*}{0,2940} & 0,358 & Valid & \multirow{10}{*}{$\begin{array}{r}0,677 \\
\text { Reliable }\end{array}$} \\
\hline & 2 & & 0,428 & Valid & \\
\hline & 3 & & 0,565 & Valid & \\
\hline & 4 & & 0,780 & Valid & \\
\hline & 5 & & 0,468 & Valid & \\
\hline & 6 & & 0,359 & Valid & \\
\hline & 7 & & 0,541 & Valid & \\
\hline & 8 & & 0,558 & Valid & \\
\hline & 9 & & 0,575 & Valid & \\
\hline & 10 & & 0,406 & Valid & \\
\hline
\end{tabular}

Based on the result of validity test on all indicator / items statement on Educational Background Variables (X1) and Work Experience Variables (X2) also Employees Performance Variables (Y) at PT. Three Cast Indonesia which was tested with SPSS version 20, it can be seen that all indicator / items statement are valid where it can be seen $r_{\text {count }}$ values off all indicators / items statement greater than $r_{\text {table }}$ of 0.1966 so that can be said that all indicators / item statement are worthy of being used as measuring tools and the entire statement item can be carried out to the next step which is reliability test.

From the table it is known that the Educational Background Variable (X1) has a croncbach alpha coefficient of 0,643 the Work Experience Variable (X2) has 0,821 and the Employee Performance Variable has 0,677 which shows results above 0 , 60 . So, from the table it can be said that the measurements of each of the questionnaire variables are reliable.

\section{F. Normality Test Result}

The data in this study used the Kolmogorov- Smirnov Test. Data is said to be normal if the value of Kolmogorov - Smirnov is $\mathrm{z}<\mathrm{z}$ table, or uses Probability $\operatorname{Sig}$ ( 2 tailed) $>\alpha$, sig $>0,05$. The test results are obtained in Table 3 as follows:

\begin{tabular}{|c|c|}
\hline \multicolumn{2}{|c|}{ TABLE II. NORMALITY TEST RESULT } \\
\hline Kolmogrov-Smirnov Test & Standardized Residual \\
\hline Kolmogorov-Smirnov Z & 0,543 \\
\hline Sig. (2-tailed) & 0,929 \\
\hline
\end{tabular}

In table 3 it can show the data that has a significant level of 0,929 shows that the significant level produced $>0,05$ the data due in this study is normally distributed.

\section{G. Multicollinearity Test Result}

Multicollinearity test is done to find out whether the independent variables correlate with each others. The guideline of a regression model that is free of multicollinearity is to have the tolerance number close to 1 . The limit of VIF is 10 , if the VIF value is below 10, then there are no symptoms of multicollinearity ${ }^{[9]}$. The test results are obtained in Table 4 as follows:

TABLE III. MULTICOLINEARITY TEST RESULT

\begin{tabular}{|l|c|c|}
\hline \multirow{2}{*}{ Model } & \multicolumn{2}{|c|}{ Collinearity Statistics } \\
\cline { 2 - 3 } & Tolerance & VIF \\
\hline Educational Background & 0,948 & 1,055 \\
\hline Work Experience & 0,948 & 1,055 \\
\hline
\end{tabular}

Based on table 4 it can be seen that the VIF value of Educational Background variable is 1,055 and for Work Experience variable is also 1,055 these result indicate that the variables are free from the classic assumption of Multicollinearity because the result are smaller than 10 or there are no symptoms or problem with multicollinearity in the regression model.

\section{H. Heteroscedasticity Test Result}

Heteroscedasticity test is done to detect the presence or absence of heteroscedasticity on a model can be seen from the image pattern of scatter plot on that model. There is no heteroscedasticity if:

1) The spread of data points should not be patterned, 
2) Data points spread above and below or around numbers 0 ,

3) Data points do not collect only above or below. The following are the results of heteroscedasticity tests:

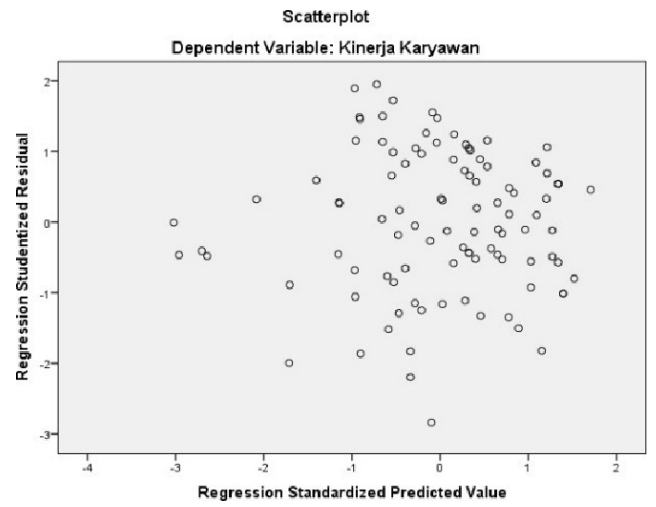

Fig. 2. Heteroscedasticity Test Result (Scatterplot)

Based on Figure 2 above, it can be concluded that this study is free from the assumption of heteroscedasticity because the data points are not patterned and spread above or below or around the numbers 0 and 3 . Or it can be concluded that there are no problems or symptoms of heterocedasticity.

\section{Multiple Linear Regression Test Result}

The results of testing the influence of independent variables (Educational Background and Work Experience) on the dependent variable (Employees Performance) using multiple linear regression tests can be seen as follows:

TABLE IV. MULTIPLE LINEAR REGRESSION TEST RESULT

\begin{tabular}{|c|c|c|c|c|c|}
\hline \multirow{2}{*}{ Model } & \multicolumn{2}{|c|}{$\begin{array}{c}\text { Unstandardized } \\
\text { Coefficients }\end{array}$} & $\begin{array}{c}\text { Standardized } \\
\text { Coefficients }\end{array}$ & \multirow{2}{*}{ t } & \multirow{2}{*}{ Sig. } \\
\cline { 2 - 4 } & B & $\begin{array}{c}\text { Std } \\
\text { Error }\end{array}$ & Beta & & \\
\hline (Constant) & 7,006 & 2,028 & & 3,455 & 0,001 \\
\hline $\begin{array}{c}\text { Educational } \\
\text { Background }\end{array}$ & 0,615 & 0,096 & 0,420 & 6,379 & 0,000 \\
\hline $\begin{array}{c}\text { Work } \\
\text { Experience }\end{array}$ & 0,418 & 0,049 & 0,562 & 8,526 & 0,000 \\
\hline
\end{tabular}

Based on the results of testing individual parameters presented in the figure above, a regression equation model can be developed:

$$
Y=7,006+0,615 X 1+0.418 \times 2
$$

From the regression equation above, it can be described as follow :

1. A constant of 7.006 shows the value of Employees Performance before it is influenced by the variable Background Education and Work Experience is positive.

2. Educational Background Variable (X1) has a value of 0,651 indicating an increase of 1 score for Educational Background will increase the Employees Performance by 0,651 assuming other independent variables are constant. The coefficient is positive, meaning that there is a positive influence between the background of education and employees performance, the better or higher the background of education, the more work performance increases.

3. Work Experience Variable (X2) has a value of 0,418 indicating an increase of 1 score for Work Experience will increase Employees Performance by 0,418 assuming other independent variables are constant. The coefficient is positive, meaning that there is a positive influence between Work Experience and Employees Performance, the more experienced the more work performance increases.

\section{J. Hypothesis Test Result}

- The result of data processing are known where tcount $6,379>$ ttable 1,661 and Sig value $0,015<0,05$. So $H_{1}$ is accepted which means there is a positive and significant influence of the Educational Background on the Employees Performance at PT. Three Cast Indonesia. And the value of tcount on the Work Experience variable (X2) is obtain at 8,526 $>$ table 1,661 with a significan value level of $0,000<0,05$. So $\mathrm{H}_{2}$ is accepted which mean there is a positive and significant effect of Work Experience on Employees Performance at PT. Three Cast Indonesia.

- From the results of the simultaneous test it can be concluded that the value of $F_{\text {count }}>$ Ftable is known by the Fcount data of 72,925 where the value is greater than Ftable of 3.09 so it can be concluded that $\mathrm{H} 3$ is accepted which means that the Educational Background variables (X1) and Work Experience variable (X2) as simultaneous have a positive effect and significant influence on Employees Performance at PT. Three Cast Indonesia.

\section{RESULTS AND DISCUSSION}

\section{A. Result and Discussion}

1. Hypothesis 1, Hypothesis test results prove that the Educational Background has a positive and significant influence on Employees Performance at PT. Three Cast Indonesia, with the results of the $t$ test of 6,379 with sig. $0.000>\alpha=0,05$. Obtained tcount 6,379 > ttable 1,661 with sig value $0,000<0,05$.

2. Hypothesis 2, Hypothesis test results prove that Work Experience has a positive and significant influence on Employees Performance at PT. Three Cast Indonesia, with the results of the $t$ test of 8,526 with sig. $0.000<\alpha$ $=0.05$. Obtained tcount 8,526> ttable 1.661 with sig value $0.000<0,05$.

3. Hypothesis 3, Hypothesis test results prove that Educational Background and Work Experience have a positive and significant influence on Employees Performance at PT. Three Cast Indonesia, with the F test results of 72,925 with sig. $0,000<\alpha=0,05$. Obtained Fcount value $72,925>$ Ftable 3,09 with sig value $0,000<$ 0,05 . 


\section{CONCLUSION \& RECOMMENDATION}

\section{A. Conclusion}

It is concluded, based on this study results, that:

1. Educational background has a positive and significant effect on employee performance at PT. Three Cast Indonesia. This is proven by $\mathrm{t}$ count value that obtained of 6,379 greater than $t$ table value of 1,661 and significance value of 0,000 smaller than 0,05 .

2. Work experience has a positive and significant effect on employee performance at PT. Three Cast Indonesia. This is proven by $t$ count value that obtained of 8,526 greater than $t$ table value of 1,661 and significance value of 0,000 smaller than 0,05 .

3. Educational background and work experience simultaneously or together has a positive and significant effect on employee performance at PT. Three Cast Indonesia. This is proven by $\mathrm{F}$ count value that obtained of 72,925 greater than $F$ table value of 3,09 and significance value of 0,000 smaller than 0,05 .

\section{B. Recommendations}

1. Based on the questionnaire on the ninth statement (Y.9) about all tasks and jobs I can finish on time, many respondents who answered strongly disagree because of the lack of time sharing by employees that makes their work unable to finish on time so that employees should begin to be able to predict and divide the time so that there is no difficulty in doing all the work in alloted time.

2. For the next study to be able to add the number of independent variables because in this study only used two independent variables namely Educational Background (X1) and Work Experience (X2).

3. To improve the performance of employees, managers or superiors should be able to place employees according to their educational background and work experience, can provide training to employees to have an understanding of the mastery of the field of work and also be able to supervise the performance of employees and do not forget to hear suggestions and employee opinion. In addition, it can also provide motivation and conduct interactions and involve the role of employees so that the employee can show better work performance than before.

\section{Limitation}

The limitations contained in this study can be described as follows:

1. Time limitation, in this study the most felt of limitation is the limited of time in which from the beginning of the research design, conducting research, distributing questionnaires, processing data to preparation of the thesis and followed by an apprenticeship report that must be completed together. If you do research more longer, it is believed that you will get more optimal research result.

2. In this study only uses two independent variables namely the Educational Background (X1) and the Work Experience (X2).

3. The method of this study only uses questionnaires.

\section{REFERENCES}

[1] Sedarmayanti. (2011). Manajemen Sumber Daya Manusia, Reformasi Birokrasi, Manajemen Pegawai Negeri Sipil. Bandung: Rafika Adhitama.

[2] Ranupandojo, H., \& Husnan, S. (2002). Manajemen Personalia Yogyakarta: BPFE.

[3] Depdiknas. (2003). Undang- undang RI No. 20 Tahun 2003 Tentang Sistem Pendidikan Nasional. Jakarta: Depdiknas.

[4] Siagian, Sondang. P. (2006). Sistem Informasi Manajemen. Jakarta:PT. Bumi Aksara.

[5] Johnson, E. B. (2007). Contextual Teaching and Learning. Bandung: Mizan Learning Center.

[6] Anwar, P. M. (2013). Manajemen Sumber Daya Manusia Perusahaan. Bandung: Remaja Rosdakarya.

[7] Anwar, P. M. (2006). Evaluasi Kinerja SDM. Jakarta: Eresco.

[8] Sugiyono. (2014). Metode Penelitian Pendidikan: Pendekatan Kuantitatif Kualitatif dan R\&D. Bandung: Alfabeta.

[9] Gujarati, D. (2012). Dasar-dasar Ekonometrika, Terjemahan mangunsong, R.C Buku 2, Edisi 5. Jakarta: Salemba Empat 